\title{
Suspended-Sediment Loads from Major Tributaries to the Missouri River between Garrison Dam and Lake Oahe, North Dakota, 1954-98
}

Water-Resources Investigations Report 00-4072

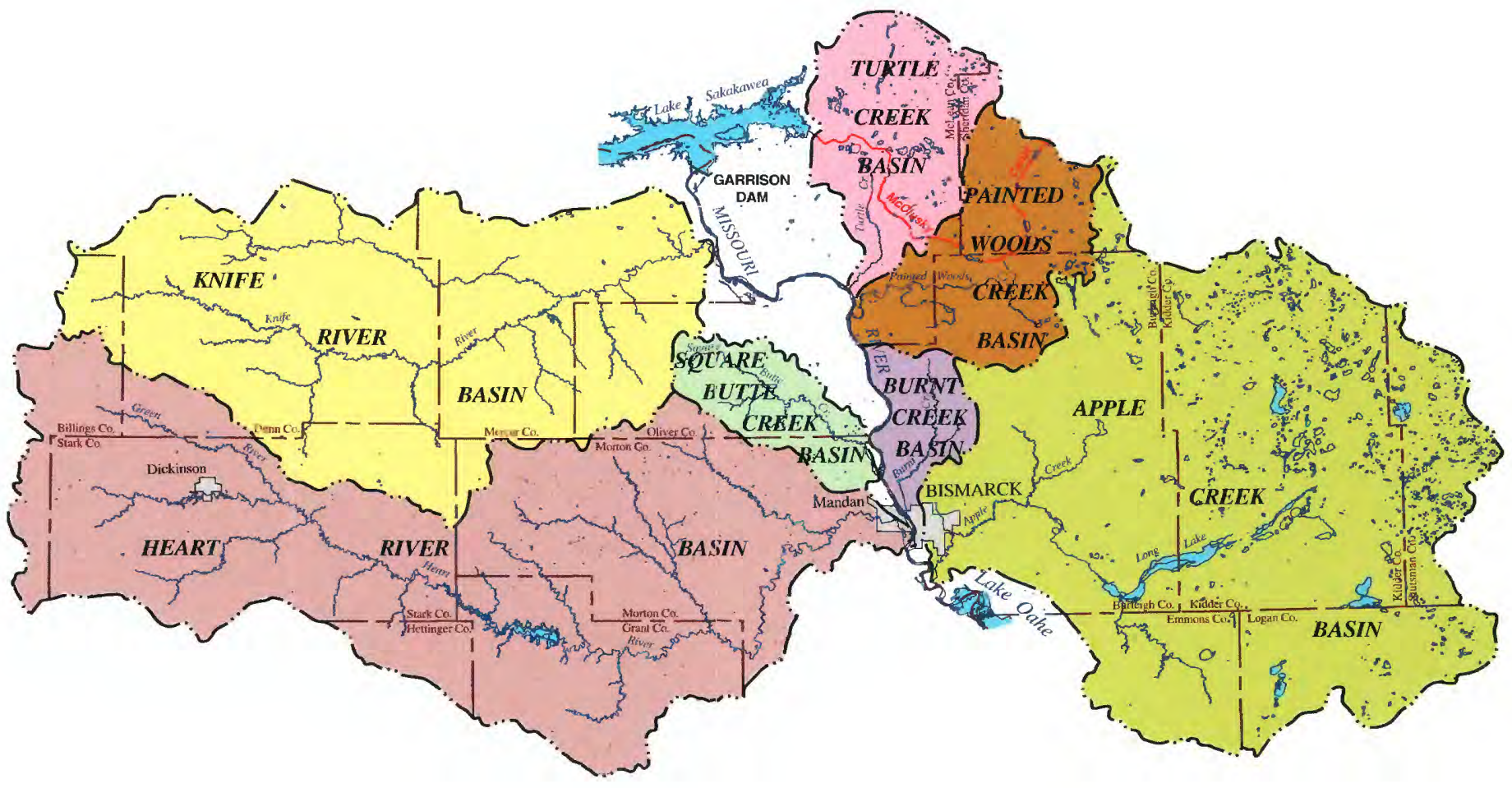




\section{Suspended-Sediment Loads from Major Tributaries to the Missouri River Between Garrison Dam and Lake Oahe, North Dakota, 1954-98}

By K. M. Macek-Rowland

Water-Resources Investigations Report 00-4072

In cooperation with the U.S. Army Corps of Engineers 
U.S. DEPARTMENT OF THE INTERIOR

BRUCE BABBITT, Secretary

U.S. GEOLOGICAL SURVEY

CHARLES G. GROAT, Director

Any use of trade, product, or firm names is for descriptive purposes only and does not imply endorsement by the U.S. Government.

For additional information write to:

District Chief

U.S. Geological Survey

Water Resources Division

821 East Interstate Avenue

Bismarck, ND 58501

Copies of this report can be purchased from:

U.S. Geological Survey

Information Services

Box 25286

Denver, CO 80225-0286 


\section{CONTENTS}

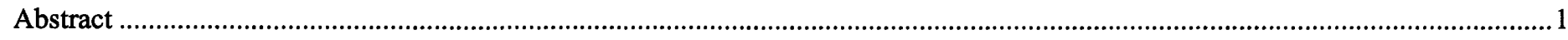

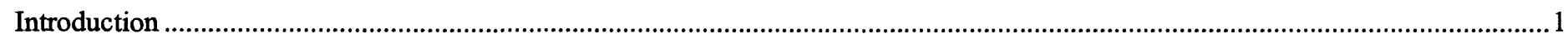

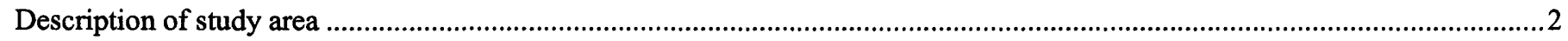

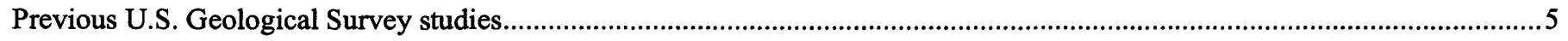

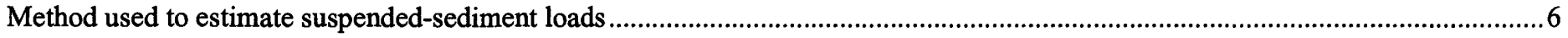

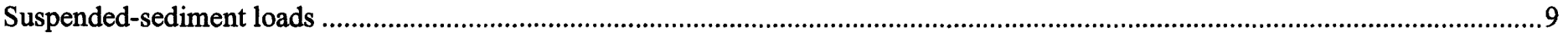

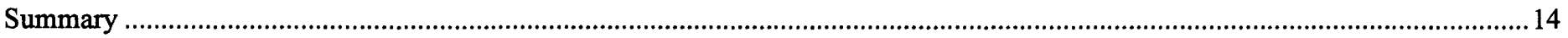

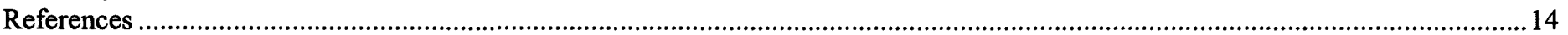

\section{FIGURES}

1. Map showing selected tributaries and basins along the Missouri River from Garrison Dam to Lake Oahe, North Dakota

2. Map showing location of selected streamflow-gaging stations along the Missouri River from Garrison Dam to Lake Oahe, North Dakota

3. Graphs showing suspended-sediment transport curves for Missouri River at Garrison Dam, Knife River at Hazen, Missouri River at Bismarck, Heart River near Mandan, and Apple Creek near Menoken, North Dakota, water years 1954 through 1998

4. Graphs showing suspended-sediment loads for Missouri River at Garrison Dam, Knife River at Hazen, Heart River near Mandan, and Missouri River at Bismarck, North Dakota, water years 1954 through 1998

5. Graphs showing suspended-sediment loads for Turtle Creek above Washburn, Painted Woods Creek near Wilton, Apple Creek near Menoken, and Missouri River at Bismarck, North Dakota, water years 1954 through 1998

6. Graphs showing suspended-sediment loads for Square Butte Creek below Center, Burnt Creek near Bismarck, and Missouri River at Bismarck, North Dakota, water years 1954 through 1998

\section{TABLES}

1. Information pertaining to selected streamflow-gaging stations in the study area.

2. Total streamflow, suspended-sediment load, and percent of suspended-sediment load entering Lake Oahe for selected streamflow-gaging stations along the Missouri River from Garrison Dam to Lake Oahe, North Dakota, water years 1954 through 1998 


\title{
Suspended-Sediment Loads from Major Tributaries to the Missouri River Between Garrison Dam and Lake Oahe, North Dakota, 1954-98
}

\author{
By Kathleen M. Macek-Rowland
}

\begin{abstract}
Annual suspended-sediment loads for water years 1954 through 1998 were estimated for the major tributaries in the Missouri River Basin between Garrison Dam and Lake Oahe in North Dakota and for the Missouri River at Garrison Dam and the Missouri River at Bismarck, N. Dak. The major tributaries are the Knife River, Turtle Creek, Painted Woods Creek, Square Butte Creek, Burnt Creek, Heart River, and Apple Creek. Sediment and streamflow data used to estimate the suspended-sediment loads were from selected U.S. Geological Survey streamflow-gaging stations located within each basin. Some of the stations had no sediment data available and limited continuous streamflow data for water years 1954 through 1998. Therefore, data from nearby streamflow-gaging stations were assumed for the calculations.

The Heart River contributed the largest amount of suspended sediment to the Missouri River for 1954-98. Annual suspended-sediment loads in the Heart River near Mandan ranged from less than 1 to 40 percent of the annual suspended-sediment load in the Missouri River. The Knife River contributed the second largest amount of suspended sediment to the Missouri River. Annual suspended-sediment loads in the Knife River at Hazen ranged from less than 1 to 19 percent of the annual suspended-sediment load in the Missouri River. Apple Creek, Turtle Creek, Painted Woods Creek, Square Butte Creek, and Burnt Creek all contributed 2 percent or less of the annual suspended-sediment load in the Missouri River. The Knife River and the Heart River also had the largest average suspended-sediment yields for the seven tributaries. The yield for the Knife River was 91.1 tons per square mile, and the yield for the Heart River was 133 tons per square mile. The remaining five tributaries had yields of less than 24 tons per square mile based on total drainage area.
\end{abstract}

\section{INTRODUCTION}

The Missouri River plays an important part in the development of human activities in the region through which it flows. The river is used for transportation, water supply, agriculture, power generation, and, more recently, recreation. Of concern to people in the region is maintaining the integrity of the unchannelized reaches of the river (those reaches between a dam and the next downstream reservoir) while promoting its use. A major factor affecting the use of the Missouri River is the amount of sediment being transported by the river. The amount of sediment being transported is important in evaluating the behavior and quality of the river. Sediment data provide information needed to determine channelmorphology changes, erosion-control measures, reservoir-storage requirements, dredging operations in channels and lakes, water-treatment procedures, toxic-substance transport and distribution as a result of sediment adsorption, and aquaticresource management. The sources of sediment in the Missouri River are the riverbed, riverbanks, and tributaries. Although these sources are readily identifiable, the amount of sediment contributed by each source is less known. Therefore, the U.S. Geological Survey, in cooperation with the U.S. Army Corps of Engineers, conducted a study to determine the amount of sediment transported by major tributaries to the Missouri River between Garrison Dam and Lake Oahe in North Dakota. The purpose of the study was to estimate annual suspended-sediment loads for the major tributaries and for the Missouri River at Garrison Dam and at Bismarck, N. Dak.

Sediment transport in the Missouri River Basin is a complex issue. Many factors affect the erosion and transport of sediment from tributary basins to the Missouri River. These factors include active factors, such as rainfall runoff and wind intensity, and passive factors, such as soil types and basin size, shape, and slope. The calculation of sediment transport using mathematical equations is difficult, if not impossible, because of the variability of these factors and the complicated 
relations among the factors (Guy, 1970). Therefore, sediment transport often is estimated as sediment load or sediment yield on the basis of existing sediment and streamflow data. The major tributaries for which suspended-sediment loads were estimated are the Knife River, Turtle Creek, Painted Woods Creek, Square Butte Creek, Burnt Creek, Heart River, and Apple Creek (fig. 1). The suspended-sediment load is the component of the total sediment load that is carried for a considerable period of time in suspension, free from contact with the streambed, and consists mainly of clay, silt, and sand particles. Sediment and streamflow data used to estimate the suspended-sediment loads for this study are from selected U.S. Geological Survey streamflow-gaging stations located within each basin (fig. 2). Estimates were made for water years ${ }^{1} 1954$ through 1998 . This period was selected because it coincides with the period of regulated flow in the Missouri River by Garrison Dam, which was completed in 1953.

This report presents results of the study. Results of the study may be used to determine the adequacy of current information and understanding and to develop sediment-management plans for the Missouri River Basin and similar areas throughout the United States.

\section{Description of Study Area}

The Missouri River is the largest river in North Dakota and accounts for 80 percent of the total mean streamflow in the State. The Missouri River Basin also is the largest drainage basin in North Dakota and consists of about 34,000 square miles in the western part of the State (see index map in fig. 1). The Missouri River flowed unrestricted for about 390 miles through North Dakota until Garrison Dam was completed by the U.S. Army Corps of Engineers in 1953. Currently (2000), about 80 miles of the river remain free-flowing between Garrison Dam and Lake Oahe.

Several tributaries flow into the Missouri River below Garrison Dam. The tributaries used in this study that are located west of the Missouri River are the Knife River, Square Butte Creek, and Heart River. These tributaries generally have larger basins than those basins located east of the river (table 1). The tributaries that flow from the west into the Missouri River occupy well-defined valleys in an area characterized by few lakes, numerous hills, and steep-sided buttes. These buttes are most prominent in an area known as the badlands in the southwest part of the State. Exposed bedrock throughout this area ranges from sandstones and shales to clays and carbonates that weather easily. Toward the river, the tributary basins are covered with a layer of glacial drift. Annual mean streamflows generally are higher in these basins than in the basins located east of the Missouri River.

The tributaries that are located east of the Missouri River are Turtle Creek, Painted Woods Creek, Burnt Creek, and Apple Creek. These tributaries generally have smaller basins than those basins located west of the Missouri River. The tributaries that flow from the east are in an area characterized by gently rolling hills and numerous small lakes and wetlands and may have considerable noncontributing drainage area. The area has some exposed bedrock, predominantly sandstones, but is dominated mainly by glacial drift and small water bodies. Annual mean streamflows generally are lower in these basins than in the basins located west of the Missouri River.

Garrison Dam is located about 70 miles north of Bismarck near Riverdale, N. Dak. The dam is one of six dams located on the main stem of the Missouri River. The dams were built by the U.S. Army Corps of Engineers, in part, to control flooding on the Missouri River. Lake Sakakawea was formed as a result of Garrison Dam and is the largest lake in North Dakota. Before the construction of the dam, the maximum peak streamflow measured at Bismarck was 500,000 cubic feet per second on April 6, 1952. For 1970-98, the annual mean streamflow at Garrison Dam was 22,670 cubic feet per second; and, for 1954-98, the annual mean streamflow at Bismarck was 23,160 cubic feet per second (table 1). About 20 miles south of Bismarck is the upstream end of Lake Oahe. Lake Oahe was formed as a result of the construction of Oahe Dam near Pierre, S. Dak.

\footnotetext{
${ }^{1}$ The 12-month period from October 1 of one year through September 30 of the next year.
} 


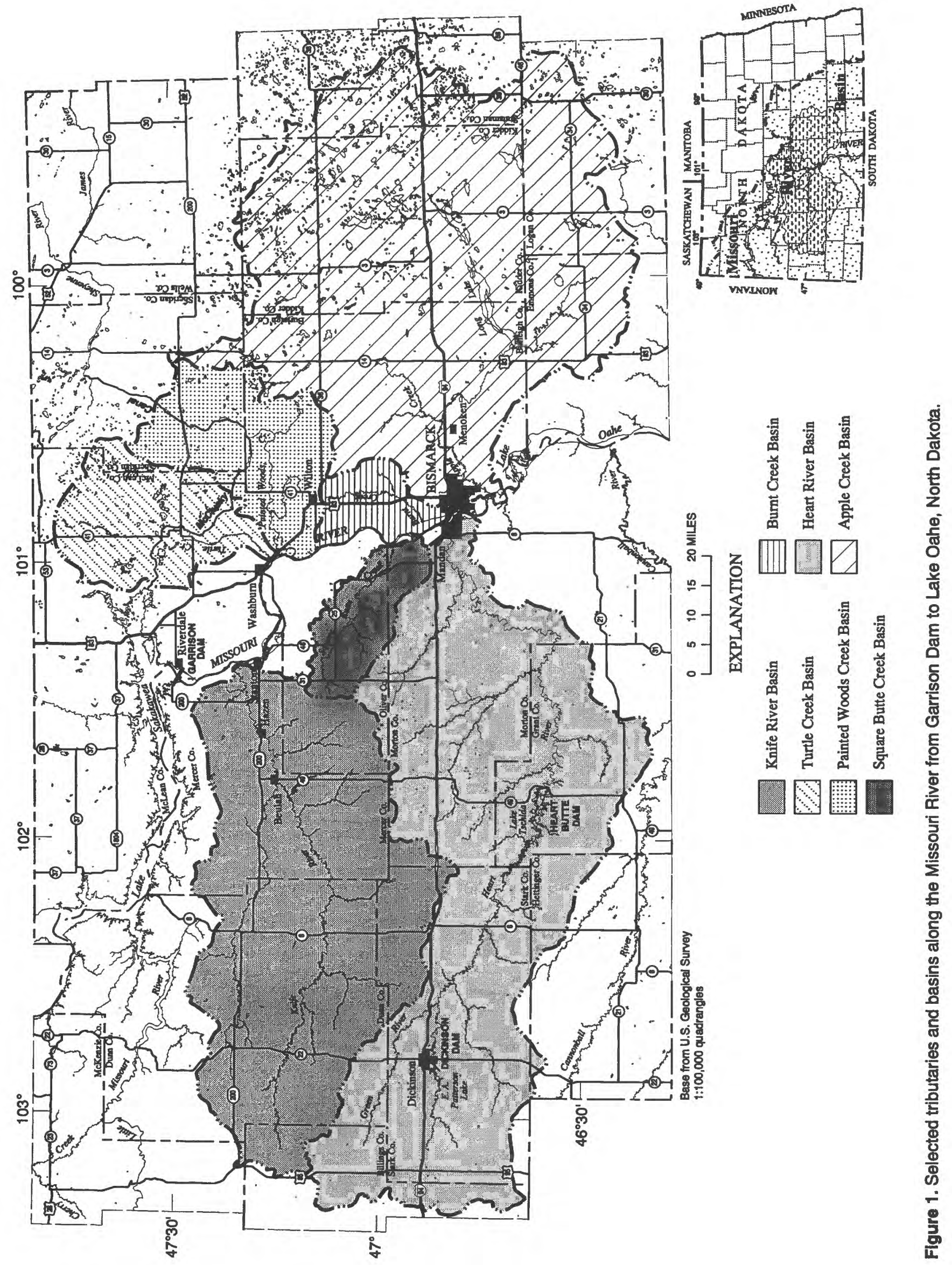




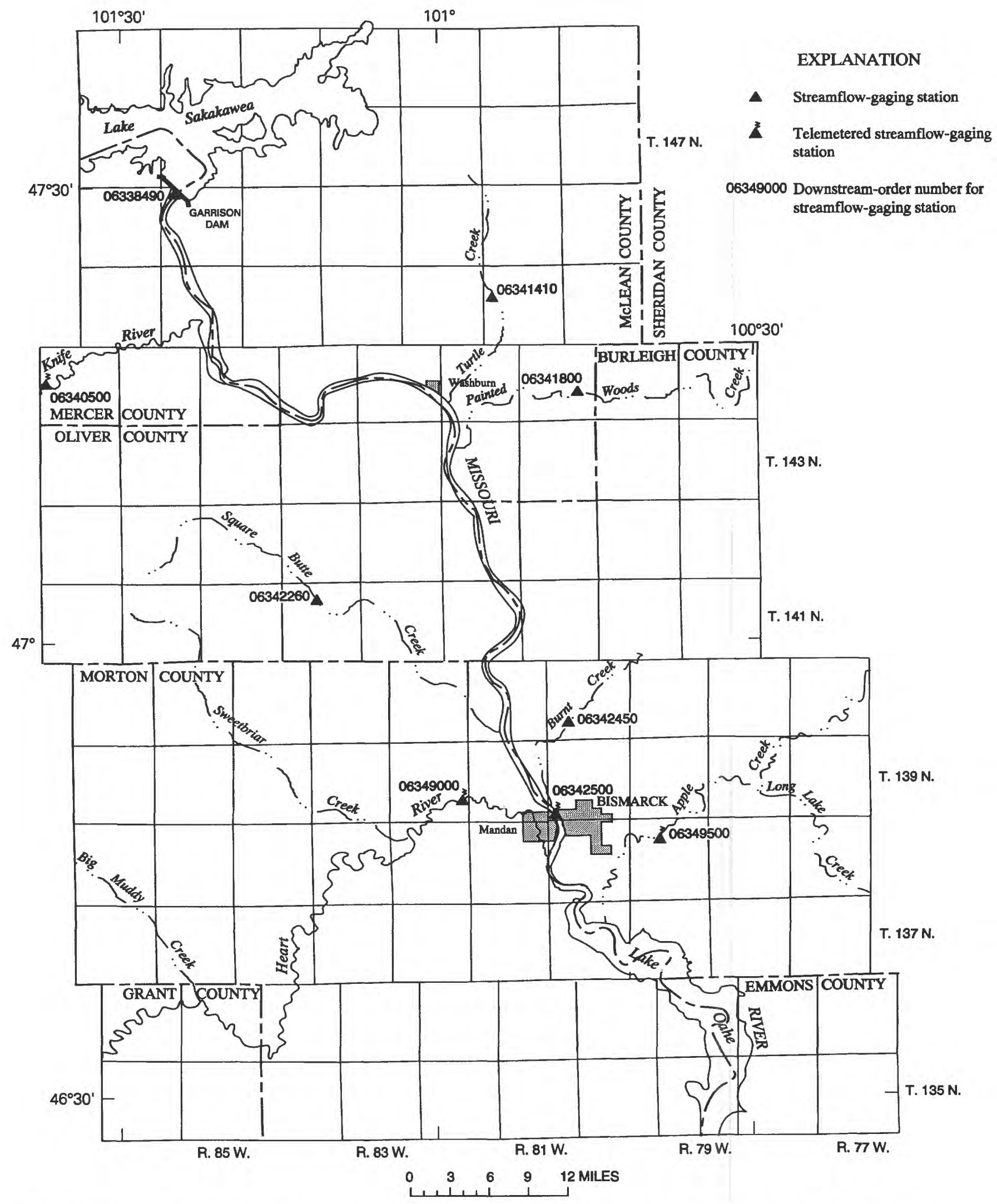

Figure 2. Location of selected streamflow-gaging stations along the Missouri River from Garrison Dam to Lake Oahe, North Dakota. 
Table 1. Information pertaining to selected streamflow-gaging stations in the study area

$\left[\mathrm{mi}^{2}\right.$, square miles; $\mathrm{ft}^{3} / \mathrm{s}$, cubic feet per second]

\begin{tabular}{|c|c|c|c|c|c|c|}
\hline $\begin{array}{l}\text { Station } \\
\text { number } \\
\text { (fig. 2) }\end{array}$ & Station name & $\begin{array}{c}\text { Total } \\
\text { drainage } \\
\text { area }^{1} \\
\left(\mathbf{m i}^{\mathbf{2}}\right)\end{array}$ & $\begin{array}{l}\text { Predominant } \\
\text { land type }\end{array}$ & Principal rock type & $\begin{array}{l}\text { Period of } \\
\text { record used } \\
\text { in analysis }\end{array}$ & $\begin{array}{c}\text { Annual mean } \\
\text { streamflow } \\
\text { for complete } \\
\text { period } \\
\text { of record } \\
\left(\mathbf{f t}^{3} / \mathbf{s}\right)\end{array}$ \\
\hline 06338490 & $\begin{array}{l}\text { Missouri River at } \\
\text { Garrison Dam, } \\
\text { N. Dak. }\end{array}$ & 181,400 & Varies & Varies & 1954-98 & 22,670 \\
\hline 06340500 & $\begin{array}{l}\text { Knife River at Hazen, } \\
\text { N. Dak. }\end{array}$ & 2,240 & $\begin{array}{c}\text { Agriculture, } \\
\text { prairie }\end{array}$ & $\begin{array}{l}\text { Sandstone, shale, siltstone, } \\
\text { lignite, carbonate, glacial } \\
\text { drift }\end{array}$ & $1954-98$ & 170 \\
\hline 06341410 & $\begin{array}{l}\text { Turtle Creek above } \\
\text { Washburn, N. Dak. }\end{array}$ & $\begin{array}{r}350 \\
(195)\end{array}$ & $\begin{array}{c}\text { Agriculture, } \\
\text { prairie } \\
\text { pothole } \\
\text { area }\end{array}$ & $\begin{array}{l}\text { Shale, sandstone, clay; } \\
\text { outwash of sand and } \\
\text { gravel }\end{array}$ & 1987-98 & 12.8 \\
\hline 06341800 & $\begin{array}{l}\text { Painted Woods Creek } \\
\text { near Wilton, N. Dak. }\end{array}$ & $\begin{array}{r}427 \\
(310)\end{array}$ & $\begin{array}{c}\text { Agriculture, } \\
\text { prairie } \\
\text { pothole } \\
\text { area }\end{array}$ & $\begin{array}{l}\text { Glacial drift, sandstone; } \\
\text { outwash of gravel and } \\
\text { sand; clay }\end{array}$ & $1958-98$ & 34.0 \\
\hline 06342260 & $\begin{array}{l}\text { Square Butte Creek } \\
\text { below Center, } \\
\text { N. Dak. }\end{array}$ & 146 & $\begin{array}{l}\text { Agriculture, } \\
\text { prairie }\end{array}$ & $\begin{array}{l}\text { Sandstone, shale, clay; } \\
\text { outwash of sand and } \\
\text { gravel; glacial drift }\end{array}$ & $1968-98$ & 11.4 \\
\hline 06342450 & $\begin{array}{l}\text { Burnt Creek near } \\
\text { Bismarck, N. Dak. }\end{array}$ & 108 & $\begin{array}{c}\text { Agriculture, } \\
\text { prairie }\end{array}$ & $\begin{array}{l}\text { Glacial drift, sandstone, } \\
\text { shale; outwash of } \\
\text { sand and gravel }\end{array}$ & 1968-98 & 7.57 \\
\hline 06342500 & $\begin{array}{l}\text { Missouri River at } \\
\text { Bismarck, N. Dak. }\end{array}$ & 186,400 & Varies & Varies & $1954-98$ & 23,160 \\
\hline 06349000 & $\begin{array}{l}\text { Heart River near } \\
\text { Mandan, N. Dak. }\end{array}$ & 3,310 & $\begin{array}{l}\text { Agriculture, } \\
\text { prairie }\end{array}$ & $\begin{array}{l}\text { Sandstone, shale, clay, } \\
\text { carbonate, evaporite, } \\
\text { glacial drift }\end{array}$ & 1954-98 & 264 \\
\hline 06349500 & $\begin{array}{l}\text { Apple Creek near } \\
\text { Menoken, N. Dak. }\end{array}$ & $\begin{array}{l}1,680 \\
(500)\end{array}$ & $\begin{array}{c}\text { Agriculture, } \\
\text { urban, } \\
\text { prairie } \\
\text { pothole } \\
\text { area }\end{array}$ & $\begin{array}{l}\text { Glacial drift; outwash of } \\
\text { sand and clay; gravel, } \\
\text { sandstone }\end{array}$ & $1954-98$ & 40.2 \\
\hline
\end{tabular}

\footnotetext{
${ }^{1}$ Number in parentheses indicates noncontributing drainage area.
}

\section{Previous U.S. Geological Survey Studies}

The sedimentation and chemical quality of surface water in the Heart River Basin was studied to provide information useful in planning the development, management, and use of the water resources in the area (Maderak, 1966). The Heart Butte and Dickinson Dams (fig. 1) were constructed on the Heart River upstream from Mandan in 1949-50 during the time of the study. The average annual suspended-sediment load for the Heart River near Mandan was estimated to be 1.3 million tons for 1945-49 before the construction of the dams. From 1950 to 1954 , the average annual suspendedsediment load was 1.03 million tons. From 1950 to 1958 , the average annual suspended-sediment load was 710,000 tons or 55 percent of the annual suspended-sediment load in the Heart River before the construction of the dams. The decrease in sediment load in the Heart River may have been caused by a decrease in higher streamflows for 1950-98. The percentage of streamflows between 120 and 10,000 cubic feet per second was smaller during 1950-58 than during 1950-54. Most of the sediment had been transported during the higher streamflows earlier in the decade. 
Suspended-sediment loads in the Knife River, the Heart River, and the Missouri River were measured for 1 day each in May 1988, May 1989, and April 1991 to determine the contributions of suspended sediment from the tributaries to the Missouri River (Berkas, 1995). On May 3, 1988, the suspended-sediment load in the Knife River was 7 percent of the suspended-sediment load in the Missouri River downstream of the Knife River, and the suspended-sediment load in the Heart River was less than 1 percent of the suspended-sediment load in the Missouri River. On May 2, 1989, the suspended-sediment load in the Knife River was 209 percent of the suspended-sediment load in the Missouri River downstream of the Knife River, and the suspended-sediment load in the Heart River was less than 1 percent of the suspended-sediment load in the Missouri River. On April 15, 1991, the contributions from both tributaries were less than 1 percent. At times, the tributaries may contribute more sediment than the river is transporting.

\section{METHOD USED TO ESTIMATE SUSPENDED-SEDIMENT LOADS}

Ideally, suspended-sediment loads for a stream or river are best determined from long-term sediment and streamflow data. However, long-term data rarely are available for more than one station in an area because of costs in manpower, equipment, and analyses. For those stations where long-term sediment data were not collected, several computation methods based on short-term or periodic sampling have been developed to estimate long-term suspended-sediment loads in streams and rivers. The sediment transport curve method described by Colby (1956) is one of the more widely used methods. In this method, a relation between streamflow and suspended-sediment concentrations is defined in terms of transport curves. According to Colby (1956), "the simplest relationship between sediment discharge and water discharge is represented by an instantaneous sediment curve. Such a curve is not affected by the extent or pattern of changes in concentration or flow. It is likely to be the most suitable curve from which to determine the effect of different factors on the basic relationship between sediment discharge and water discharge and on departures from this relationship."

Although, theoretically, transport curves should be used to compute sediment loads only for very short time intervals, they frequently are used satisfactorily to compute daily suspended-sediment loads from daily streamflow data. Therefore, the sediment transport curve method was used to estimate annual suspended-sediment loads for the nine streamflow-gaging stations used in this study for water years 1954 through 1998.

The sediment data used in this report were collected according to methods described by Guy and Norman (1970). The most common of these methods are the single vertical method and the multiple vertical method. In the single vertical method, samples are collected at a single vertical at a stream cross section. In the multiple vertical method, samples are collected at multiple verticals at either equal width increments or equal discharge increments across a stream cross section. The data collected by these methods are considered to be suspended-sediment concentrations and are reported in milligrams per liter. Instantaneous streamflow usually is measured at the same time the samples are collected and is reported in cubic feet per second.

The sediment discharge data used in this report were determined by multiplying the suspended-sediment concentrations, in milligrams per liter, by the instantaneous streamflows, in cubic feet per second, and by a coefficient factor that is based on the unit of measurement of water discharge and that assumes a specific weight of 2.65 for sediment (Porterfield, 1972). The sediment discharge data, in tons per day, were used in a regression equation with streamflow, in cubic feet per second, to determine the transport curves. These curves then were used to estimate the annual suspendedsediment loads for the nine streamflow-gaging stations.

To aid in the computation of the suspended-sediment loads, the software program S-PLUS 2000 was used. S-PLUS 2000 is a statistical program written in an interpreted language in which individual language expressions are read and immediately executed. Suspended-sediment concentrations that had corresponding instantaneous streamflows were retrieved from the U.S. Geological Survey's National Water Information System (NWIS) data base. These data were placed in specified formats for use in S-PLUS 2000 to enable the calculation of sediment transport curves (fig. 3). Daily mean streamflow data for water years 1954 through 1998 for each station were retrieved from NWIS, entered into S-PLUS 2000 , and used with the transport curves to compute the daily suspended-sediment loads, in tons per day. The daily suspended-sediment loads then were summed to estimate the annual suspended-sediment loads, in tons per year, for each station.

Streamflow and sediment data were used to develop transport curves for five of the nine streamflow-gaging stations (fig. 3). The transport curve for the Missouri River at Garrison Dam was developed as a reference base for sediment 

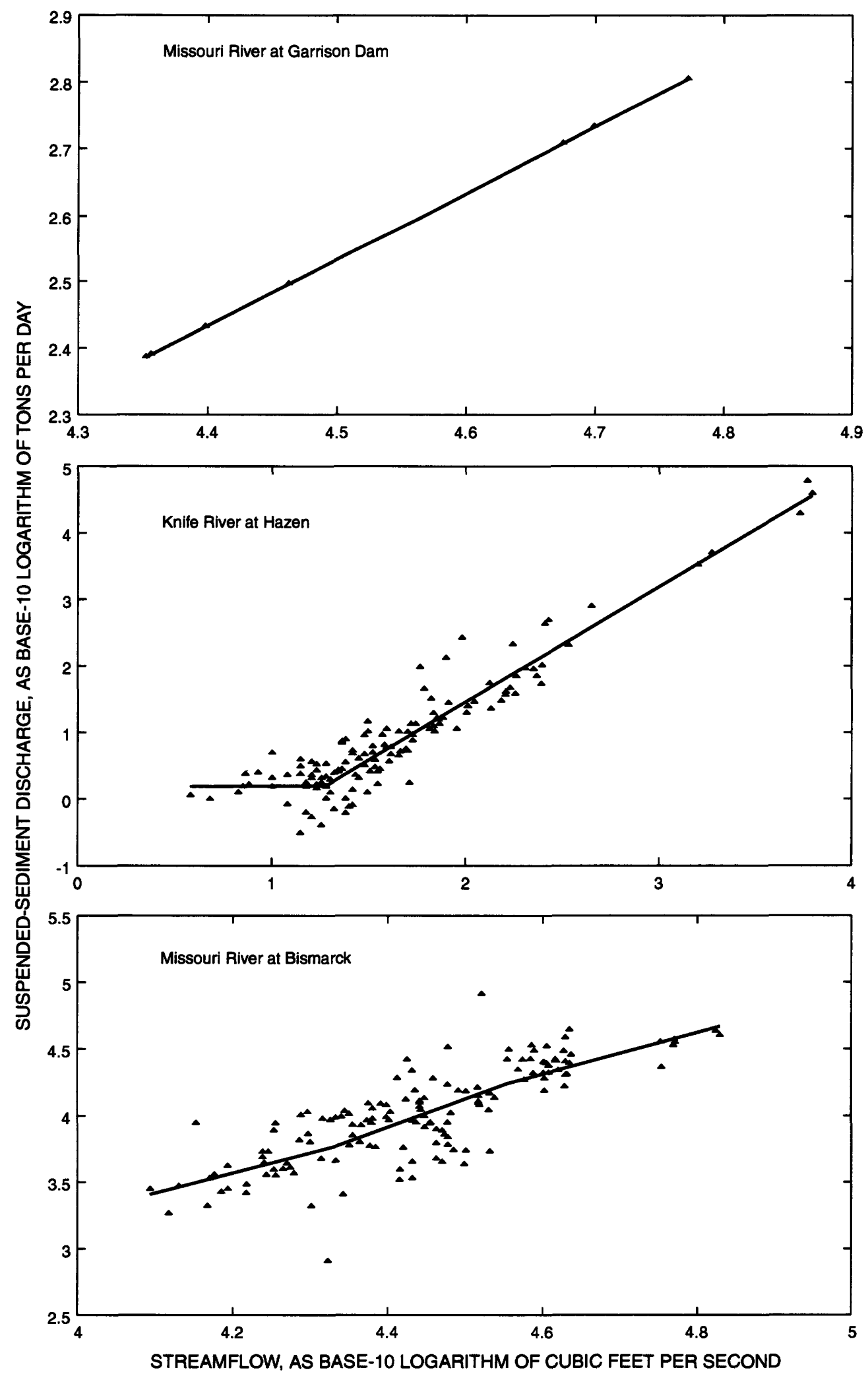

Figure 3. Suspended-sediment transport curves for Missouri River at Garrison Dam, Knife River at Hazen, Missouri River at Bismarck, Heart River near Mandan, and Apple Creek near Menoken, North Dakota, water years 1954 through 1998. 

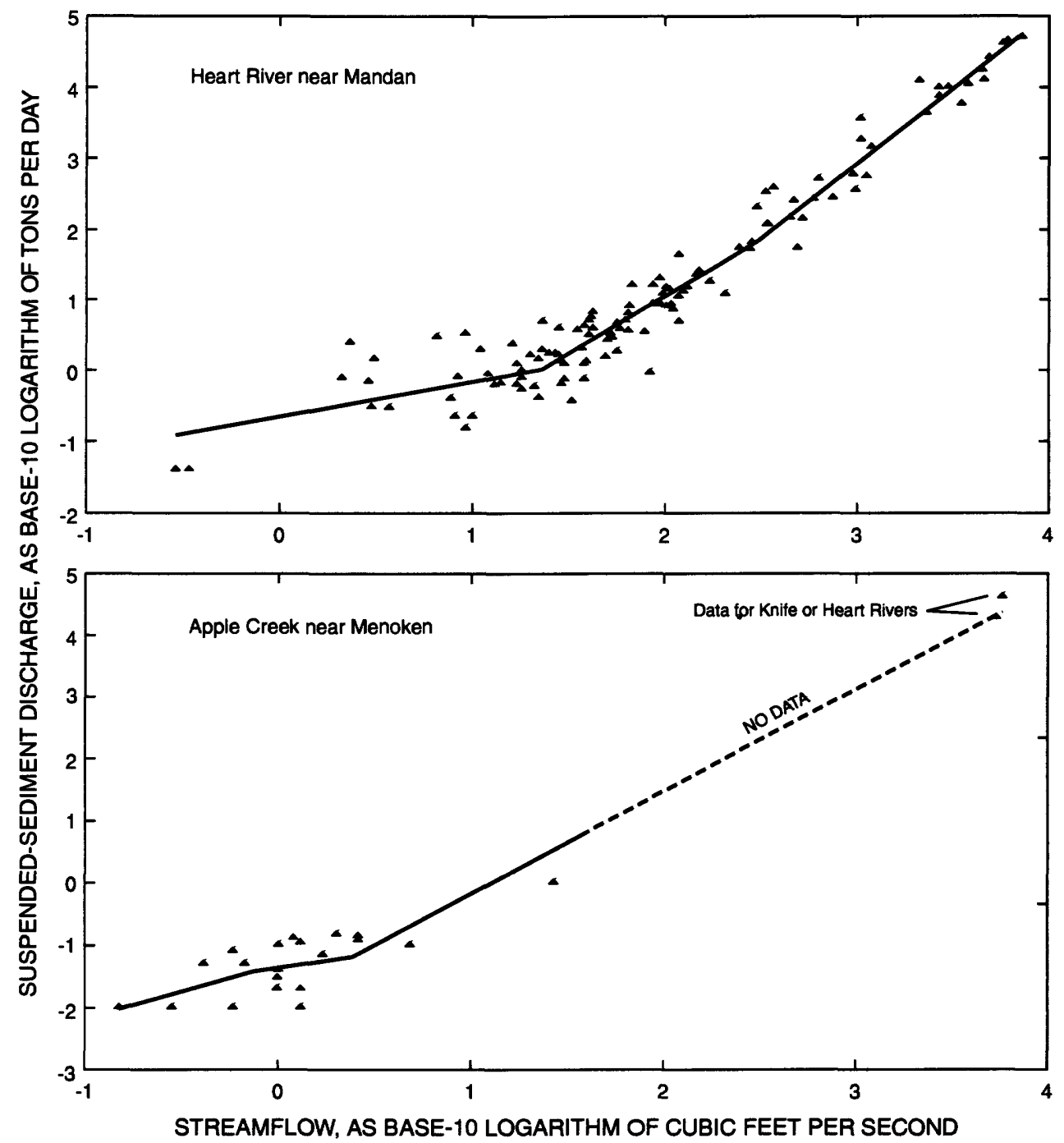

Figure 3. Suspended-sediment transport curves for Missouri River at Garrison Dam, Knife River at Hazen, Missouri River at Bismarck, Heart River near Mandan, and Apple Creek near Menoken, North Dakota, water years 1954 through 1998--Continued. 
transport between Garrison Dam and Lake Oahe. However, because the amount of sediment data available for the Missouri River at Garrison Dam was limited, the transport curve for that station may be considered adequate at best. A greater amount of sediment data was available for the Knife River, the Missouri River at Bismarck, and the Heart River, so those sediment transport curves may be considered good.

The sediment data for Apple Creek were limited to data collected during low and medium streamflows. Therefore, extrapolation of the upper end of the sediment transport curve for Apple Creek was done on the basis of two high-flow data points from the Knife River and the Heart River. The transport curves for the Knife River and the Heart River indicate similar relations between sediment discharge and streamflow. Therefore, using data points from these rivers seemed to be the best solution for the limited amount of data for Apple Creek. These data points were not out of range for the streamflows for Apple Creek and provided a more complete transport curve, especially at higher streamflows.

For those stations where long-term sediment data were not collected, data from a nearby station located in a basin with similar characteristics were assumed for the calculations. Turtle Creek, Painted Woods Creek, Square Butte Creek, and Burnt Creek had no sediment data available and limited continuous streamflow data. Therefore, the transport curve for Apple Creek was used to estimate the annual suspended-sediment loads (summed daily loads) for those tributaries. The Turtle Creek, Painted Woods Creek, and Burnt Creek Basins are located on the same side of the Missouri River as the Apple Creek Basin. Those basins are smaller than the Apple Creek Basin but have similar basin characteristics. The Square Butte Creek Basin is located on the opposite side of the river but is more similar to the eastern basins than to the Knife River and Heart River Basins. The upper end of the sediment transport curve for Apple Creek may be high when used for the smaller tributaries because the Apple Creek Basin is larger than the other four basins, but suspended-sediment loads obtained for the four smaller tributaries were reasonable. For those years when no sediment or streamflow data were collected for Turtle Creek, Painted Woods Creek, Square Butte Creek, and Burnt Creek, the median of the total streamflow for the period of record and the median of the corresponding annual suspended-sediment load were used.

To compare the annual suspended-sediment loads for each station and the annual suspended-sediment load in the Missouri River, a theoretical site was chosen at the headwaters of Lake Oahe. The total annual streamflow and annual suspended-sediment load for this site were determined by combining data from the Heart River, Apple Creek, and Missouri River at Bismarck. The Heart River and Apple Creek were included because they are located downstream of the Missouri River at Bismarck. Data for other sources entering the Missouri River downstream of Bismarck and upstream from Lake Oahe were not included because contributions from those sources were considered to be minimal in this analysis.

\section{SUSPENDED-SEDIMENT LOADS}

Total annual streamflows and annual suspended-sediment loads for waters years 1954 through 1998 for the nine streamflow-gaging stations used in this study and for the theoretical site at the headwaters of Lake Oahe are given in table 2 at the end of the report. The percentage of annual suspended-sediment load each tributary contributed to the annual suspended-sediment load in the Missouri River entering Lake Oahe also is given in table 2. Generally, higher streamflows have higher velocities that detach more sediment from the stream or river channel. This sediment then is transported downstream. Usually, the higher streamflows occur during extreme events such as spring breakup or an isolated thunderstorm and may not be lengthy in duration. However, the highest annual suspended-sediment loads do not necessarily coincide with the highest total annual streamflows. For example, in any given year, a few days or weeks of extremely high streamflow may result in the highest annual suspended-sediment load for the period of record. The total annual streamflow for a year could be low because of some days or weeks of extremely low flow during that year. For example, the highest annual suspended-sediment load for the Heart River near Mandan occurred in 1997, but the highest total annual streamflow for that station occurred in a different year. During low-flow years on the Missouri River, the larger tributaries could contribute a substantial amount of suspended sediment to the river because of an unusual event occurring in the tributary basin but not on the main stem or in other tributary basins. In 1993, the annual suspendedsediment load for the Heart River near Mandan was about 33 percent of the total suspended-sediment load in the Missouri River. For the Missouri River at Bismarck, 1993 was the third lowest year, during 1954-98, for the percentage of annual suspended-sediment load in the Missouri River. In 1960, the annual suspended-sediment load for the Knife River at Hazen was about 19 percent of the total suspended-sediment load in the Missouri River. This percentage was the highest for the Knife River during 1954-98. For the Missouri River at Bismarck, however, 1960 was the lowest year for both total annual streamflow and annual suspended-sediment load during 1954-98. 
Annual suspended-sediment loads in the Missouri River at Garrison Dam ranged from 1 to 4 percent of the annual suspended-sediment load in the Missouri River (table 2). Annual suspended-sediment loads ranged from 51,800 to 130,000 tons per year (table 2, fig. 4). The fairly low percentage of sediment contribution is because the dam acts as a trap for sediment entering Lake Sakakawea from upstream. Because the dam impedes the flow, velocities decrease and sediment begins to settle in the lake before the water is released from the dam.

The Heart River contributed the largest amount of suspended sediment to the Missouri River for 1954-98 (table 2). Annual suspended-sediment loads in the Heart River near Mandan ranged from less than 1 to 40 percent of the annual suspended-sediment load in the Missouri River. Annual suspended-sediment loads ranged from 617 to 3 million tons per year (table 2, fig. 4). The Knife River contributed the second largest amount of suspended sediment to the Missouri River. Annual suspended-sediment loads in the Knife River at Hazen ranged from less than 1 to 19 percent of the annual suspended-sediment load in the Missouri River (table 2). Annual suspended-sediment loads ranged from 1,460 to 1.12 million tons per year (table 2, fig. 4). Apple Creek contributed the third largest amount of suspended sediment to the Missouri River, but the load was very low when compared to those from the Heart and Knife Rivers. Annual suspendedsediment loads in Apple Creek near Menoken ranged from less than 1 to 2 percent of the annual suspended-sediment load in the Missouri River (table 2). Annual suspended-sediment loads ranged from 7.5 to 192,000 tons per year (table 2, fig. 5).

For the remaining four tributaries--Turtle Creek, Painted Woods Creek, Square Butte Creek, and Burnt Creek--annual suspended-sediment loads for 1954-98 were less than 1 percent of the annual suspended-sediment load in the Missouri River (table 2). Annual suspended-sediment loads for Turtle Creek ranged from 38 to 4,330 tons per year, loads for Painted Woods Creek ranged from 9 to 26,100 tons per year, loads for Square Butte Creek ranged from 22 to 24,600 tons per year, and loads for Burnt Creek ranged from 0.14 to 9,060 tons per year (table 2, figs. 5 and 6).

Sediment yields indicate the amount of sediment per square mile that is being contributed by a basin and are calculated by dividing the sediment load by the area of the basin. The average suspended-sediment yield for each of the seven tributaries used in this study is given in the following table:

\begin{tabular}{lcc}
\hline \multicolumn{1}{c}{ Station name } & $\begin{array}{c}\text { Average suspended- } \\
\text { sediment yield }\end{array}$ & $\begin{array}{c}\text { Percent of area in } \\
\text { Missouri River Basin } \\
\text { between Garrison Dam } \\
\text { and Lake Oahe }\end{array}$ \\
\hline Knife River at Hazen, N. Dak. & 91.1 & 22 \\
Turtle Creek above Washburn, N. Dak. & 2.90 & 4 \\
Painted Woods Creek near Wilton, N. Dak. & $(6.5)$ & 4 \\
Square Butte Creek below Center, N. Dak. & 8.10 & 1 \\
Burnt Creek near Bismarck, N. Dak. & $(29.5)$ & 1 \\
Heart River near Mandan, N. Dak. & 22.2 & 33 \\
Apple Creek near Menoken, N. Dak. & 23.3 & 17 \\
\hline
\end{tabular}

${ }^{1}$ Based on total drainage area; values in parentheses based on contributing drainage area.

The Knife River and the Heart River have the two largest suspended-sediment yields and the two largest drainage areas in the Missouri River Basin between Garrison Dam and Lake Oahe. Square Butte Creek and Burnt Creek have the next largest suspended-sediment yields but the smallest drainage areas in the Missouri River Basin between Garrison Dam and Lake Oahe. Turtle Creek, Painted Woods Creek, and Apple Creek have smaller suspended-sediment yields than Square Butte Creek and Burnt Creek but larger drainage areas. Parts of Turtle Creek, Painted Woods Creek, and Apple Creek Basins are classified as noncontributing (table 1). When the noncontributing area is removed from the sediment- 


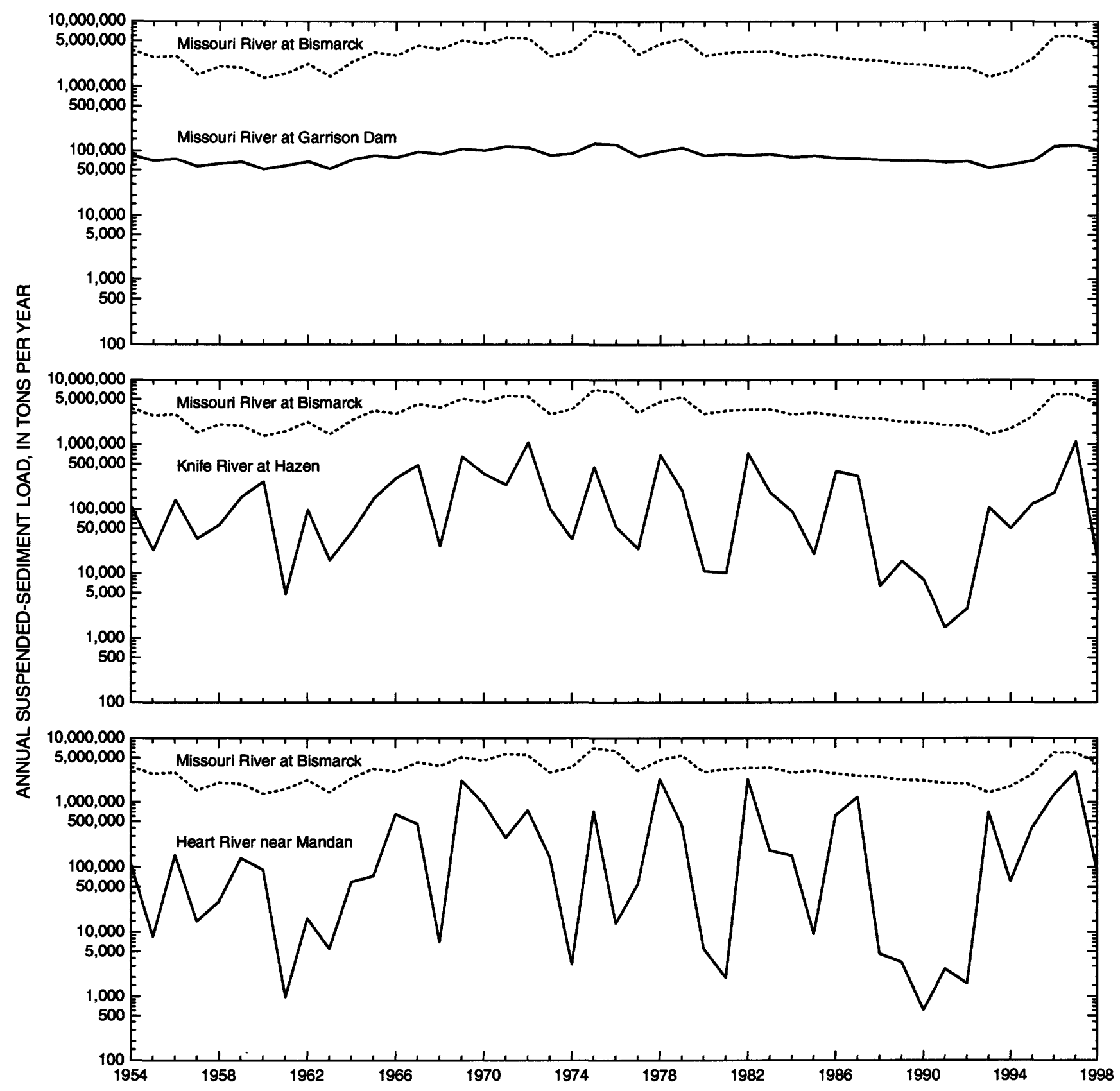

Figure 4. Suspended-sediment loads for Missouri River at Garrison Dam, Knife River at Hazen, Heart River near Mandan, and Missouri River at Bismarck, North Dakota, water years 1954 through 1998. 


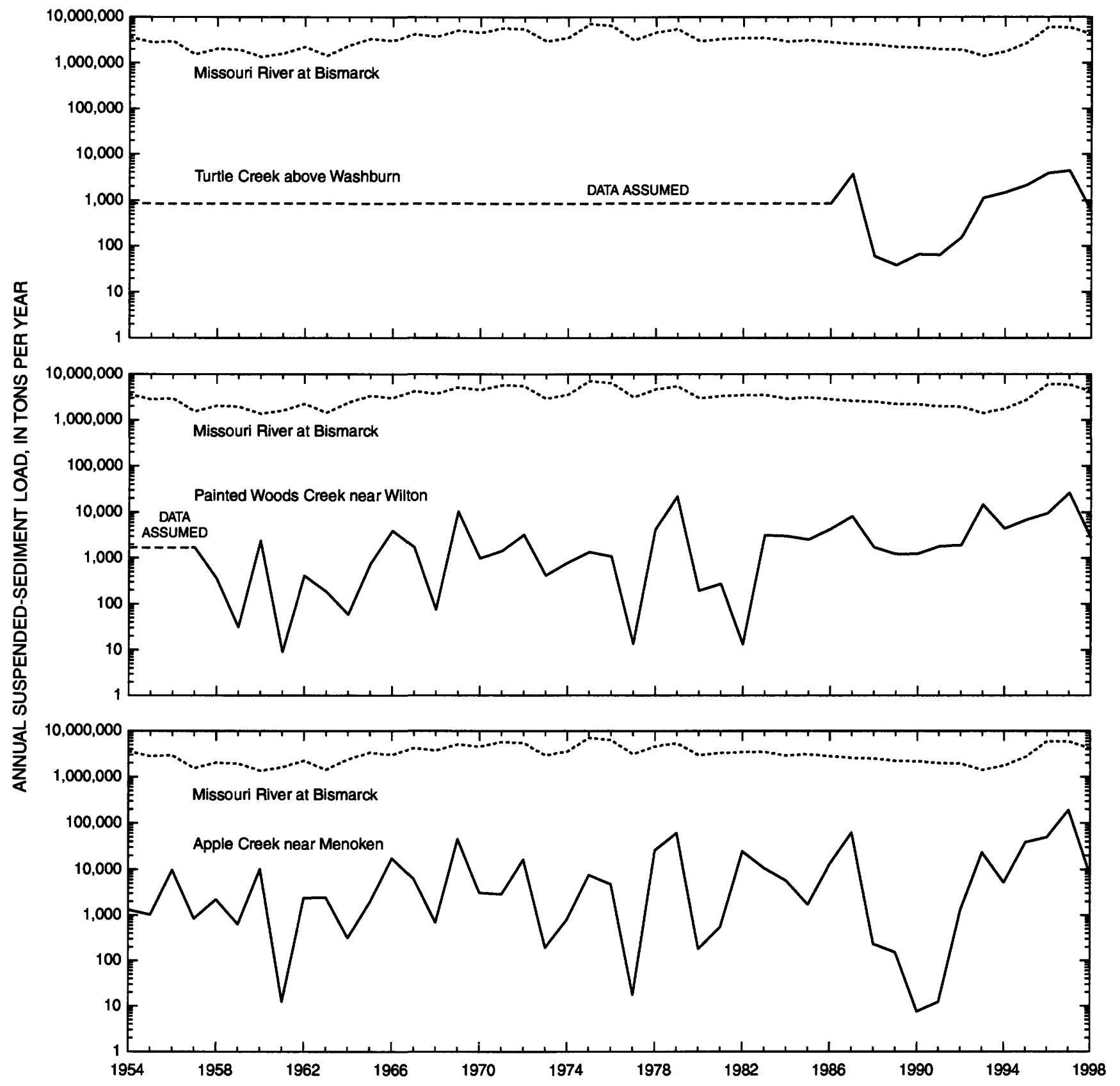

Figure 5. Suspended-sediment loads for Turtle Creek above Washburn, Painted Woods Creek near Wilton, Apple Creek near Menoken, and Missouri River at Bismarck, North Dakota, water years 1954 through 1998. 

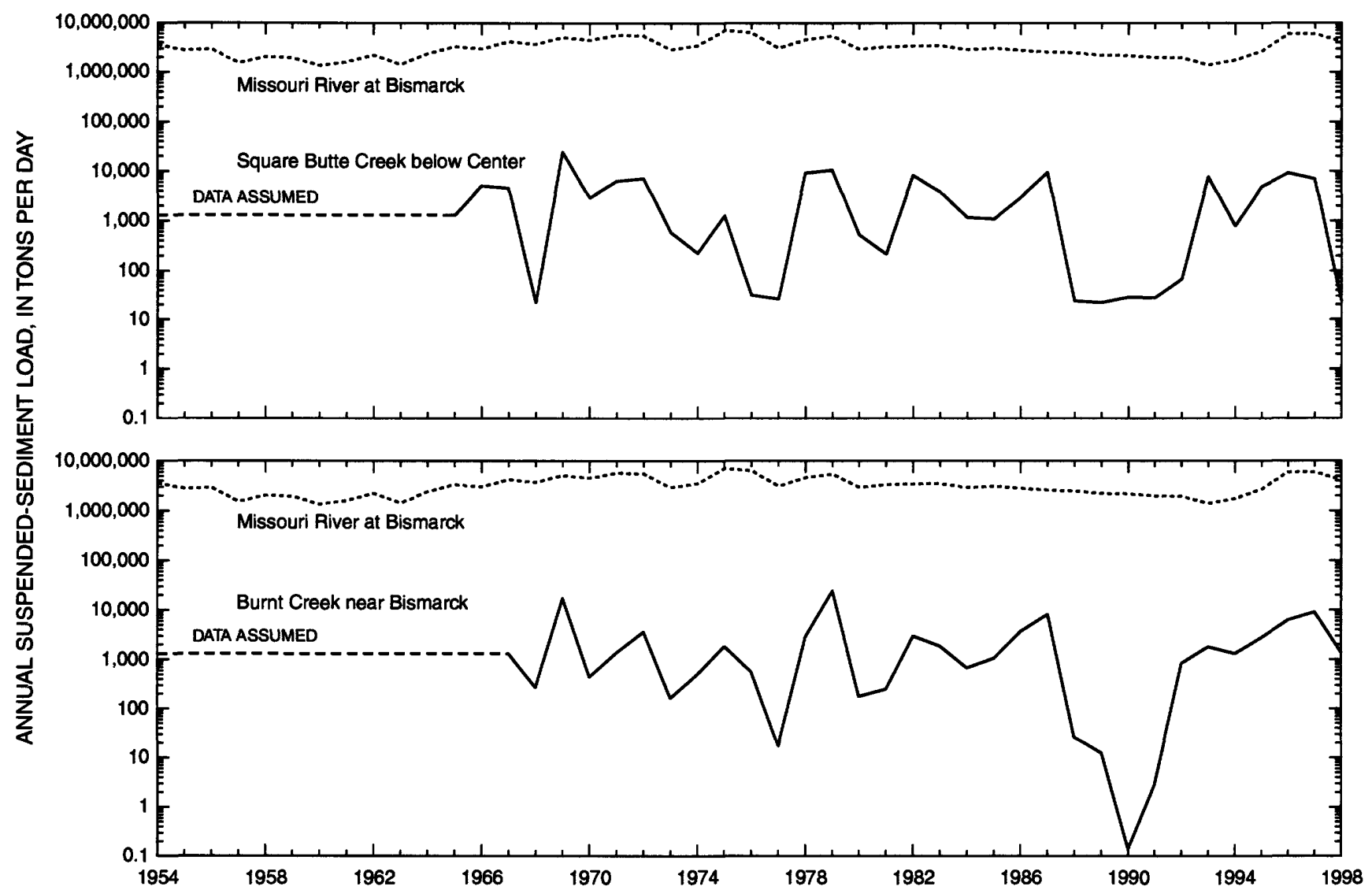

Figure 6. Suspended-sediment loads for Square Butte Creek below Center, Burnt Creek near Bismarck, and Missouri River at Bismarck, North Dakota, water years 1954 through 1998. 
yield calculation for Turtle Creek, Painted Woods Creek, and Apple Creek, only the average suspended-sediment yield for Painted Woods Creek surpasses the yields for Square Butte Creek and Burnt Creek.

Some areas between Garrison Dam and Lake Oahe were not included in this study (fig. 1). These areas comprise less than 20 percent of the area between Garrison Dam and Lake Oahe, and streamflow and sediment data have not been collected for most, if not all, of the tributaries in those areas. Although sediment transport is occurring in those areas, it possibly does not amount to more than 1 to 2 percent of the total suspended-sediment load entering the Missouri River. For those areas next to the Missouri River channel, additional studies may be useful to quantify the bank erosion caused by the flow in the river.

\section{SUMMARY}

Annual suspended-sediment loads for water years 1954 through 1998 were estimated for the major tributaries in the Missouri River Basin between Garrison Dam and Lake Oahe in North Dakota and for the Missouri River at Garrison Dam and the Missouri River at Bismarck, N. Dak. The major tributaries are the Knife River, Turtle Creek, Painted Woods Creek, Square Butte Creek, Burnt Creek, Heart River, and Apple Creek. Sediment and streamflow data used to estimate the suspended-sediment loads were from selected U.S. Geological Survey streamflow-gaging stations located within each basin. Some of the stations had no sediment data available and limited continuous streamflow data for water years 1954 through 1998. Therefore, data from nearby streamflow-gaging stations were assumed for the calculations.

The Heart River contributed the largest amount of suspended sediment to the Missouri River for 1954-98. Annual suspended-sediment loads in the Heart River near Mandan ranged from less than 1 to 40 percent of the annual suspendedsediment load in the Missouri River. The Knife River contributed the second largest amount of suspended sediment to the Missouri River. Annual suspended-sediment loads in the Knife River at Hazen ranged from less than 1 to 19 percent of the annual suspended-sediment load in the Missouri River. Apple Creek, Turtle Creek, Painted Woods Creek, Square Butte Creek, and Burnt Creek all contributed 2 percent or less of the annual suspended-sediment load in the Missouri River. The Knife River and the Heart River also had the largest suspended-sediment yields for the seven tributaries. The yield for the Knife River was 91.1 tons per square mile, and the yield for the Heart River was 133 tons per square mile. The remaining five tributaries had yields of less than 24 tons per square mile based on total drainage area.

The estimated suspended-sediment loads presented in this report may be used to help identify sediment sources to the Missouri River between Garrison and Lake Oahe. Results of the study may be used to determine the adequacy of current information and understanding and to develop sediment-management plans for the Missouri River Basin.

\section{REFERENCES}

Berkas, W.R., 1995, Transport and sources of sediment in the Missouri River between Garrison Dam and the headwaters of Lake Oahe, North Dakota, May 1988 through April 1991: U.S. Geological Survey Water-Resources Investigations Report 95-4087, 26 p.

Colby, B.R., 1956, Relationship of sediment discharge to streamflow: U.S. Geological Survey, Quality of Water Branch, Open-file report, $170 \mathrm{p}$.

Guy, H.P., 1970, Fluvial sediment concepts: U.S. Geological Survey Techniques of Water-Resources Investigations, book 3, chap. C1, $55 \mathrm{p}$.

Guy, H.P., and Norman, V.W., 1970, Field methods for measurement of fluvial sediment: U.S. Geological Survey Techniques of Water-Resources Investigations, book 3, chap. C2, $59 \mathrm{p}$.

Maderak, M.L., 1966, Sedimentation and chemical quality of surface water in the Heart River drainage basin, North Dakota: U.S. Geological Survey Water-Supply Paper 1823, 42 p.

Porterfield, George, 1972, Computation of fluvial-sediment discharge: U.S. Geological Survey Techniques of Water-Resources Investigations, book 3, chap. C3, $66 \mathrm{p}$. 


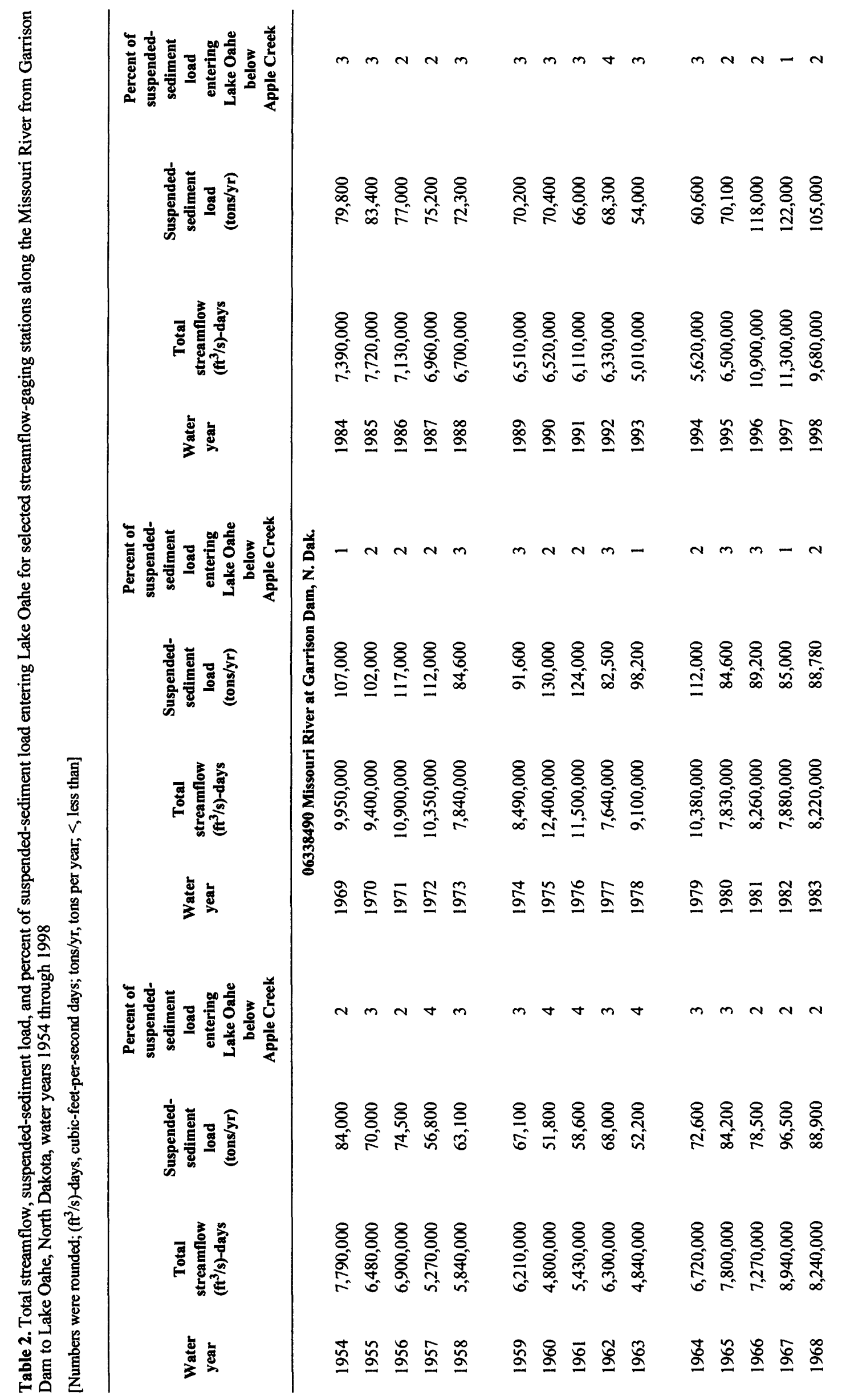




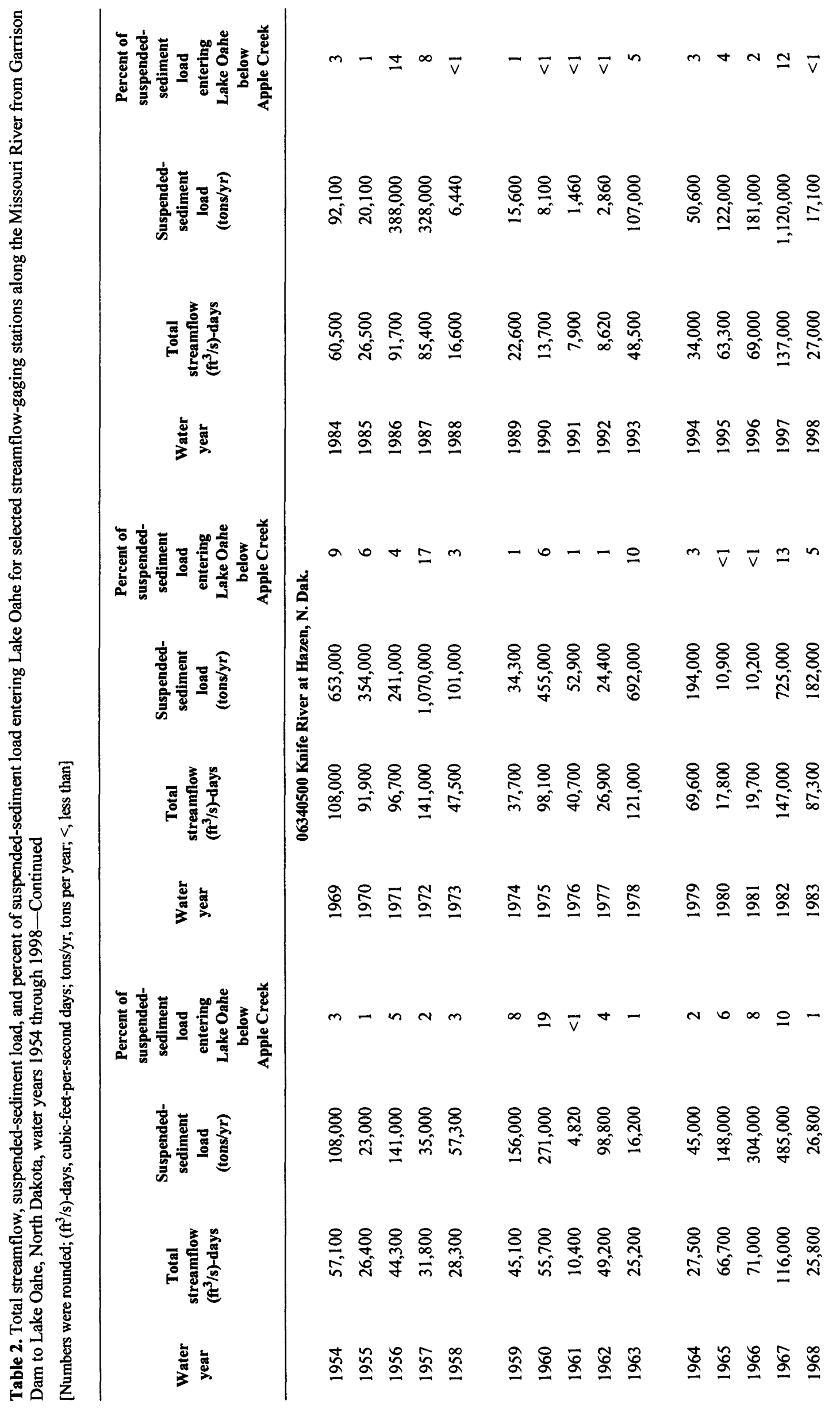




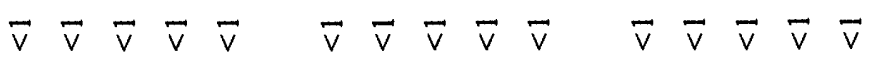

UI!

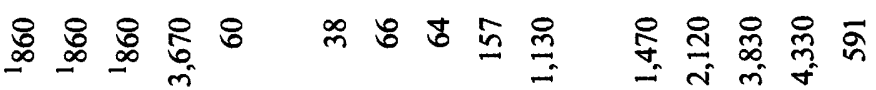

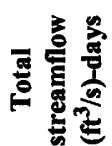

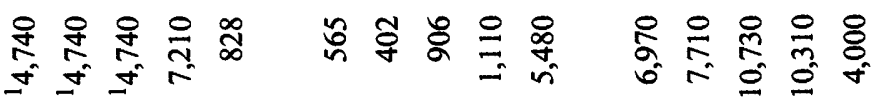

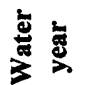

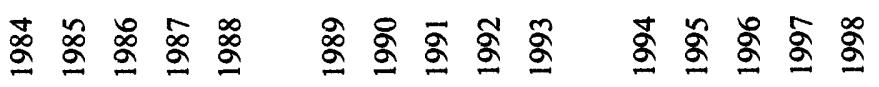

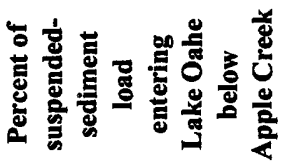

III

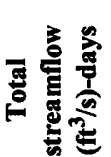

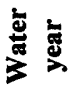

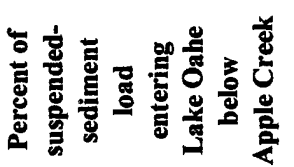

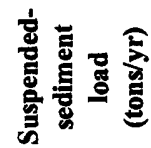

衰高旁旁

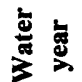

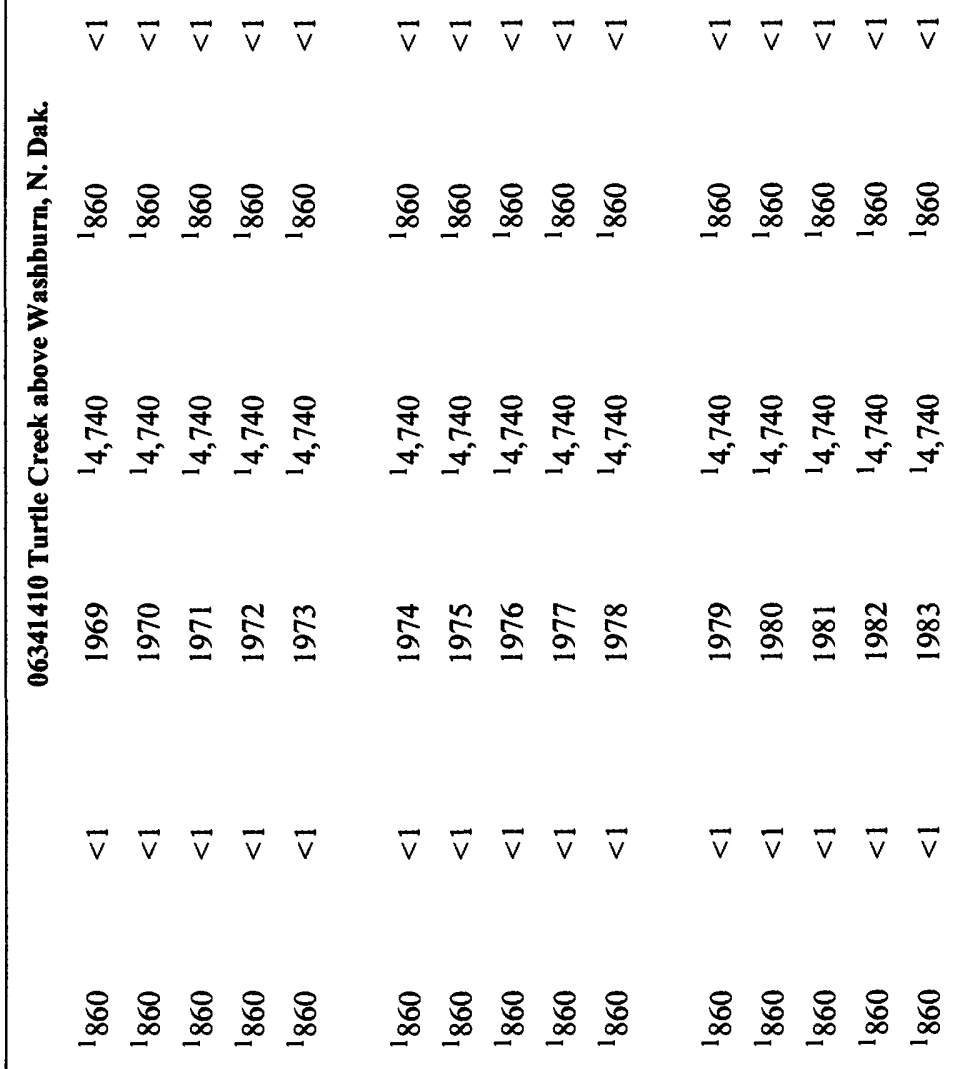

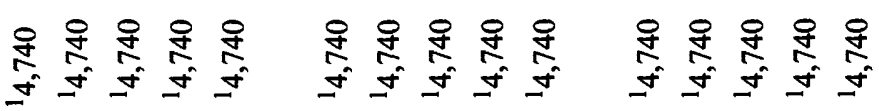

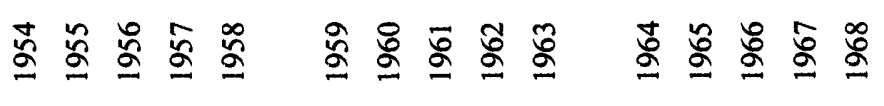




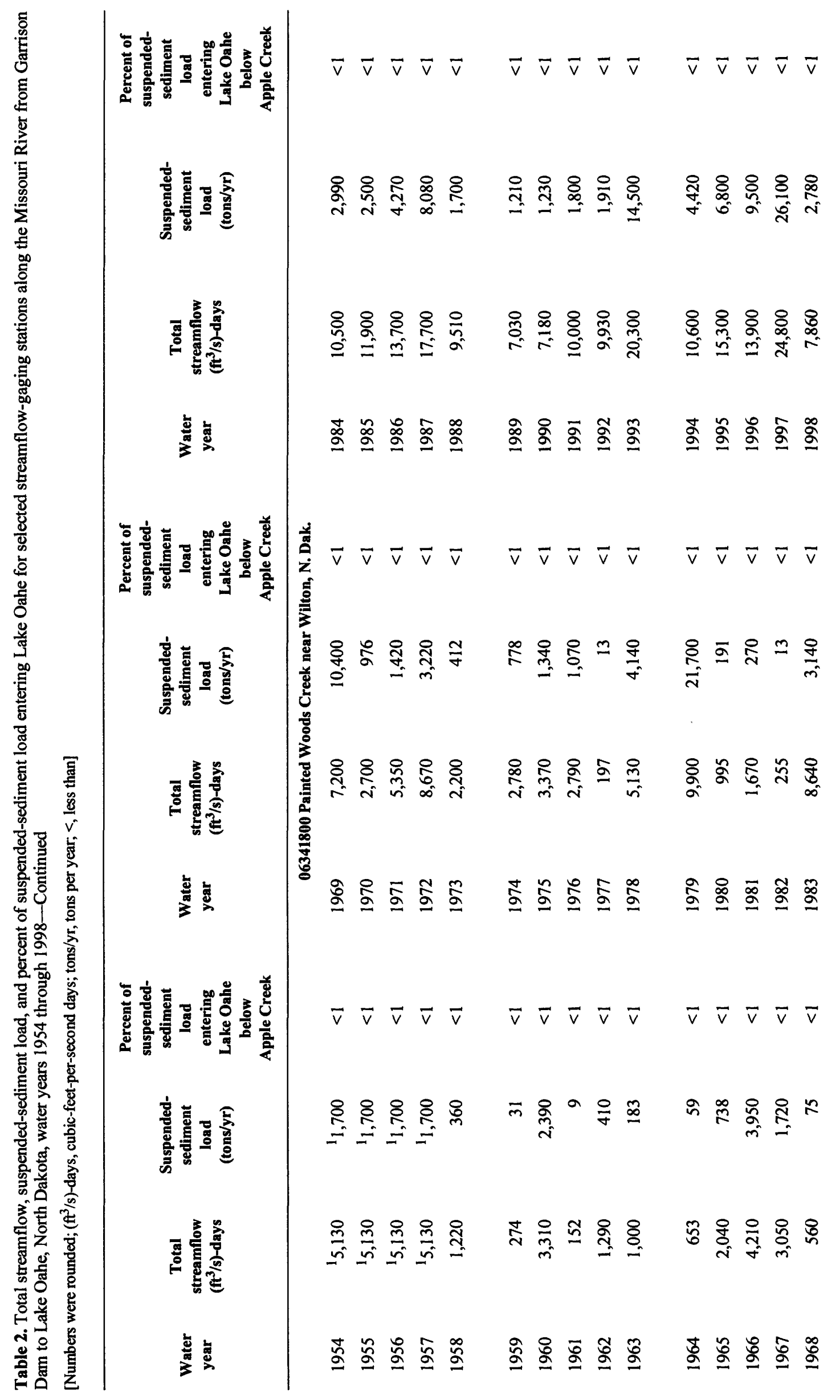




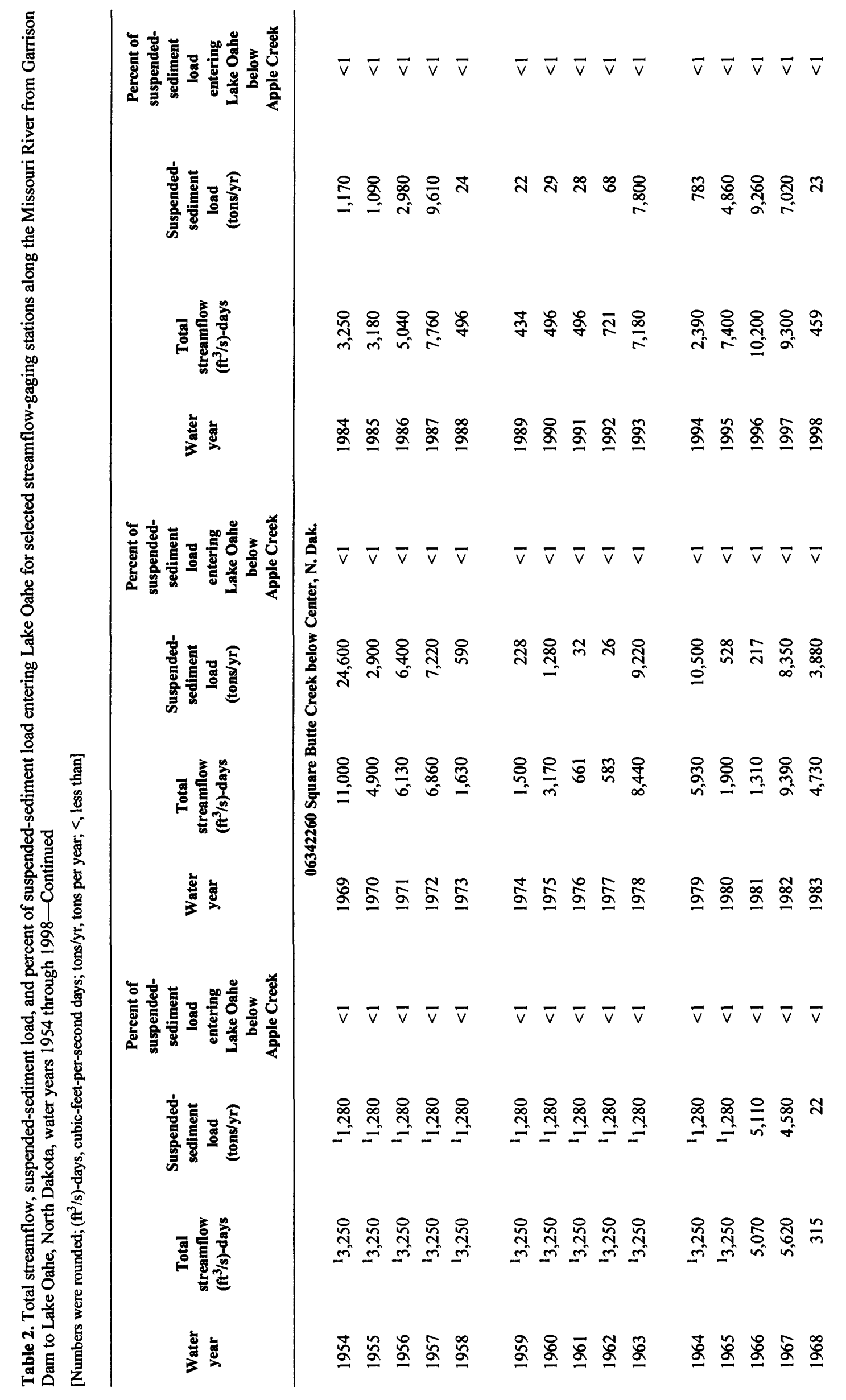




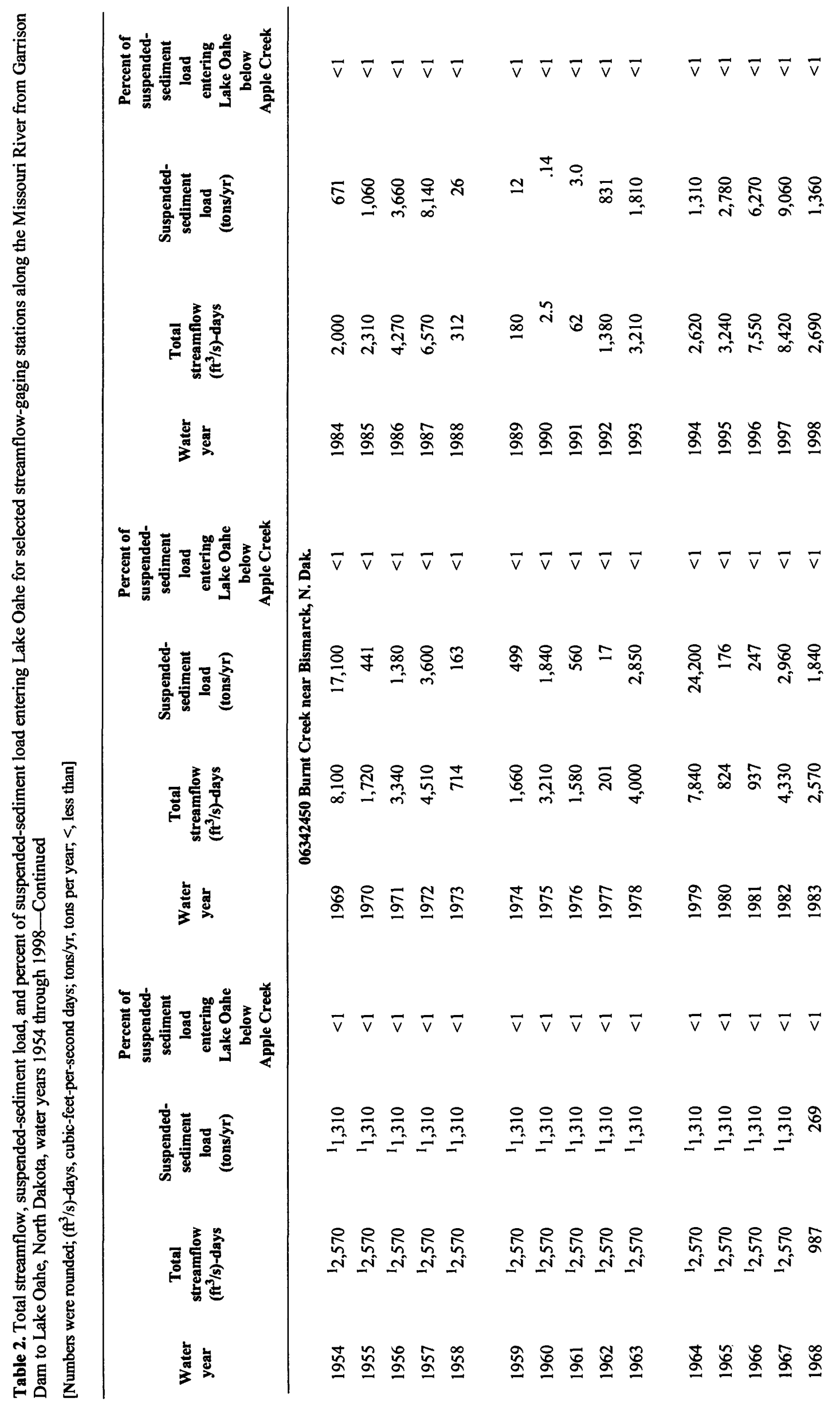


IIIิ

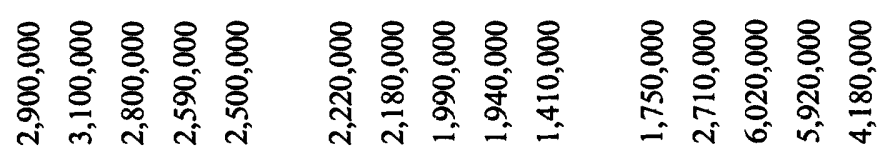

恛

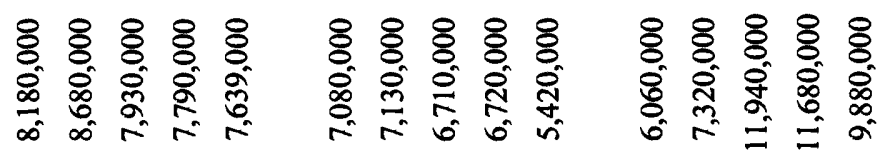

竎弯

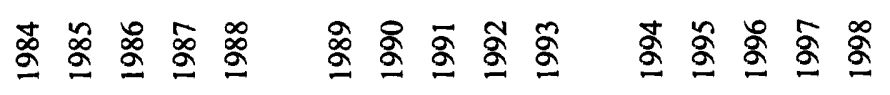

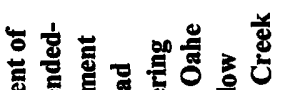

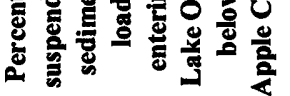

min

!I

离离

每

E⿱丷天心

俩

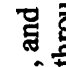

is

要

要

in

要

要

응

(

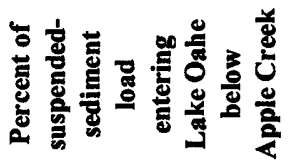

MI!

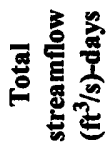

离

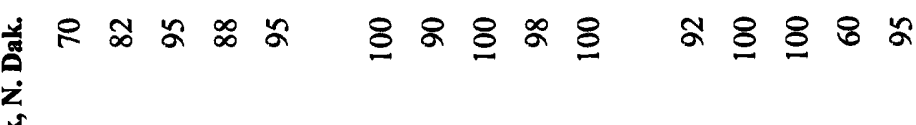

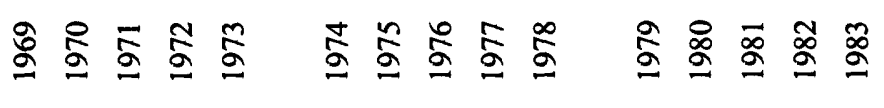

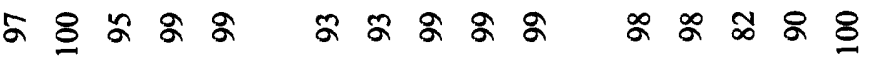

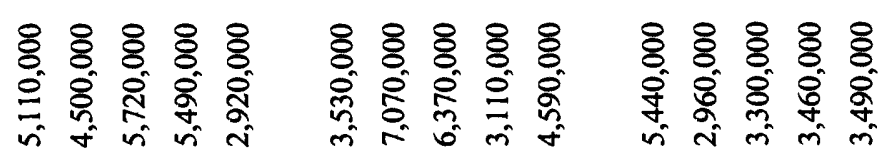

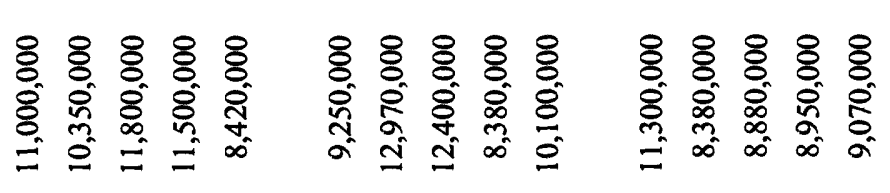

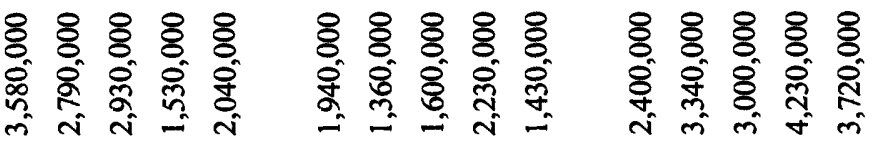

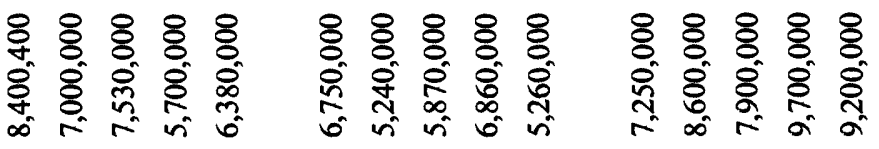

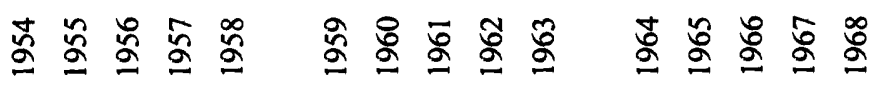




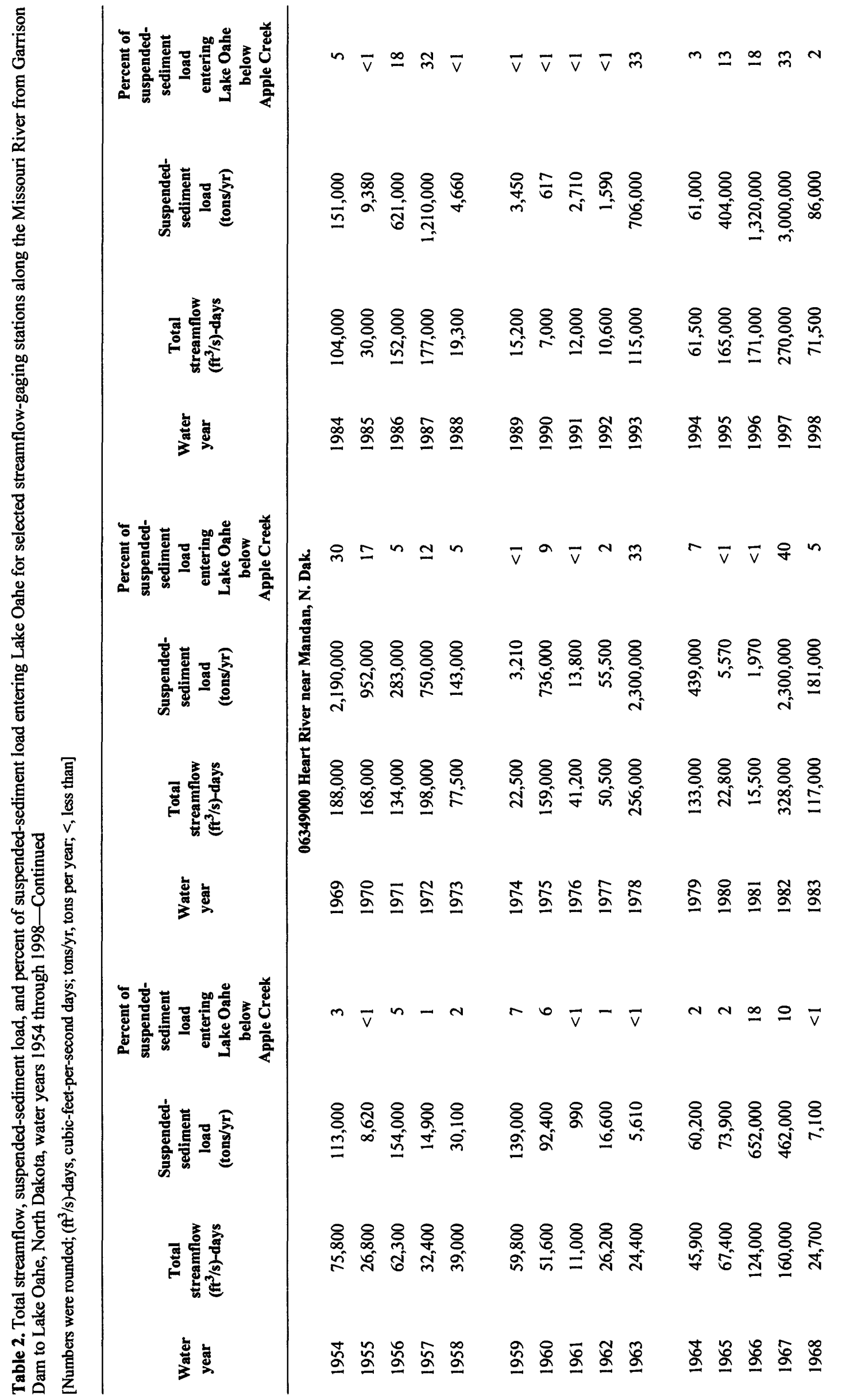




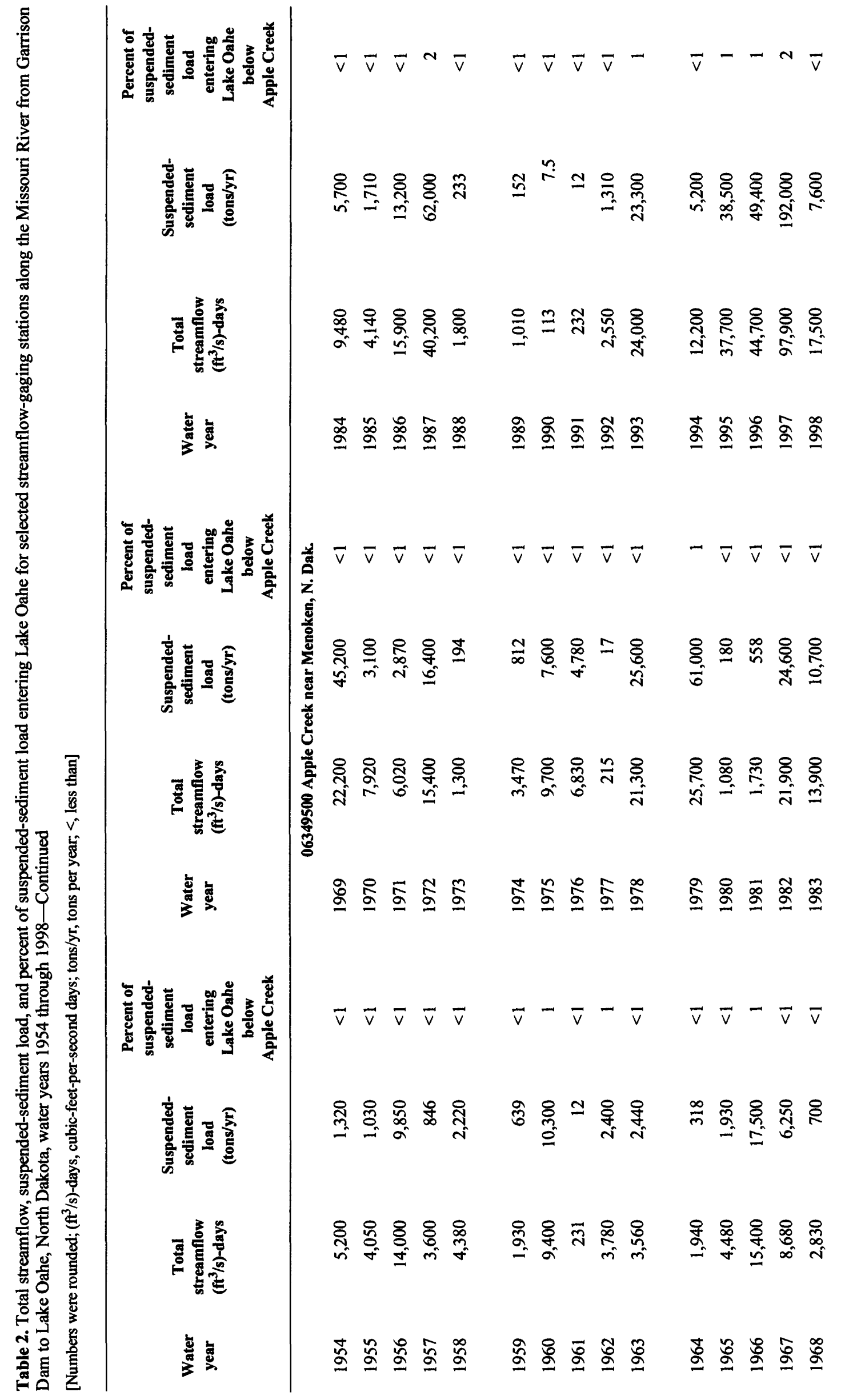




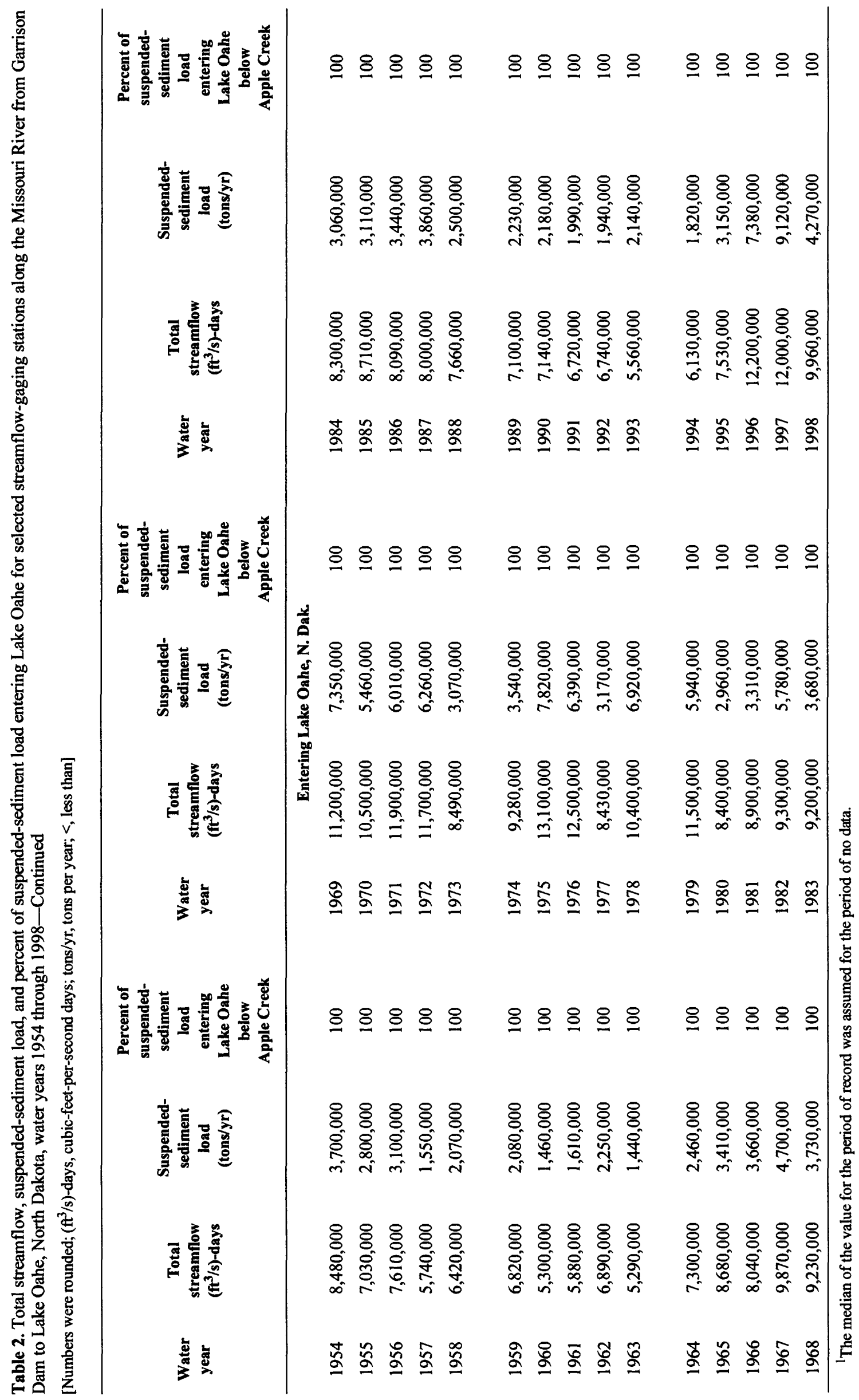

